\title{
2. LOW CRUSTAL MAGNETIZATION OF THE MIDDLE VALLEY SEDIMENTED RIFT INFERRED FROM SEA-SURFACE MAGNETIC ANOMALIES ${ }^{1}$
}

\author{
R.G. Currie ${ }^{2}$ and E.E. Davis ${ }^{2}$
}

\begin{abstract}
Middle Valley, a sediment-filled seafloor spreading rift at the northern end of the Juan de Fuca Ridge, is situated roughly at the center of the Brunhes magnetic anomaly but is characterized by a pronounced magnetic low. Forward modelling, constrained by seismic data and measured magnetization of rocks recovered during Ocean Drilling Program Leg 139, demonstrates that this magnetic feature is consistent with the presence of essentially nonmagnetic crust beneath Middle Valley. The low level of magnetization is the result of extensive hydrothermal alteration that has taken place beneath the hydrologic seal of sediment in the valley. The transition from the nonmagnetic crust beneath the valley to "normal" crust outside is sharp, and its position is reasonably approximated by the zero contour of the sea-surface magnetic anomaly field. Parallel to the valley axis, the transition roughly coincides with the major normal faults that currently bound the valley. Outside the zone of low magnetization but within the Brunhes central magnetic anomaly, the crust is more typically magnetized, and further to the east, a nearly uninterrupted sequence of seafloor spreading magnetic anomalies is present, suggesting that the sediment-filled Middle Valley rift is a recent feature of the northern Juan de Fuca Ridge, and that it was preceded by a more normal, thinly sedimented, volcanic rift environment.
\end{abstract}

\section{INTRODUCTION}

The Juan de Fuca Ridge stretches $550 \mathrm{~km}$ between the Blanco and Sovanco transform faults. Over most of its length its structure is typical of that of medium to fast spreading-rate spreading centers. The ridge is subdivided into five principal segments (e.g., Johnson and Holmes, 1989) in a manner characteristic of other ridge systems (Macdonald et al., 1988). At most segments, rifting occurs at the summits of high-standing volcanic ridges constructed where the supply of volcanic material for crustal creation is abundant (Kappel and Ryan, 1986; Davis and Currie, 1993). An exception to this morphology occurs at the northern end of the ridge, near its intersection with the Sovanco transform fault, where the supply of crustal material at the axis is currently restricted, and rifting has produced the deep axial rift, Middle Valley (Fig. 1). The combination of this structure and the abundant supply of turbidite sediments during the Pleistocene has caused the valley to be filled with sediment as the lithosphere beneath has extended (Davis and Villinger, 1992). This has caused the igneous rocks that have been added to the crust recently to be intruded into the sediment section (Shipboard Scientific Party, 1992a; Langseth and Becker, this volume) instead of extruded onto the seafloor in the way usually seen at seafloor spreading centers. The sediment also serves to thermally insulate and hydrologically seal the crust. As a result, temperatures in the igneous crust beneath the sediment fill are thought to be ubiquitously high, in the order of $300^{\circ} \mathrm{C}$ (Shipboard Scientific Party, 1992a), well above the Curie temperature of unaltered basalt.

Numerous discussions (Irving, 1970; Larson et al., 1972; Atwater and Mudie, 1973; Davis and Lister, 1977; Curray et al., 1978; Levi and Riddihough, 1986) have focused on an inferred consequence of igneous crust being produced by intrusion into a high-temperature sedimentary section: that the crust does not acquire remanent magnetization in the same way that extrusive crust does, and as a result, the source layer that normally produces seafloor-spreading magnetic anomaly lineations is not created. In the case of Middle Valley, it has been suggested but not quantitatively demonstrated that the large negative sea-surface magnetic anomaly centered at the ridge axis is caused by the locally low magnetization of the crustal rocks beneath

\footnotetext{
${ }^{1}$ Mottl, M.J., Davis, E.E., Fisher, A.T., and Slack, J.F. (Eds.), 1994. Proc. ODP, Sci. Results, 139; College Station, TX (Ocean Drilling Program).

${ }^{2}$ Pacific Geoscience Centre, Geological Survey of Canada, P.O. Box 6000, Sidney, B.C. V8L 4B2, Canada.
}

the valley (Davis and Lister, 1977). During Ocean Drilling Program (ODP) Leg 139, the intrusive rocks beneath and within the sediment fill of Middle Valley were sampled at Site 857, allowing the magnetic properties of the rocks to be examined directly. Magnetic studies (Shipboard Scientific Party, 1992b; Fukuma et al., this volume) have quantified the low levels of magnetization and susceptibility of these rocks and identified the specific cause of the low values. In this paper we demonstrate with simple, forward models that the unusual anomaly over the valley can be generated by the low magnetization. Using the constraints provided by the sea-surface magnetic anomaly over Middle Valley together with the measured magnetizations and model results, we estimate the extent of the altered crust created.

\section{NORMAL AND ANOMALOUS CRUSTAL MAGNETIZATION}

\section{Compositional Variations and Hydrothermal Alteration}

A global comparison of Brunhes marine magnetic anomalies reveals regional variations in amplitude that exceed those expected from differences in latitude, ridge orientation, and other geometric factors (Vogt and Byerly, 1976). For example, both the Galapagos spreading axis (Vogt and De Boer, 1976) and the Juan de Fuca Ridge (Vogt and Johnson, 1973) have been described as having anomalously high-amplitude Brunhes magnetic anomalies. These regional variations are probably associated with differences in average magnetization due to variations in rock compositions; the basalts of both the Juan de Fuca Ridge and the Galapagos rift are characterized by high iron and titanium content (Vogt and Byerly, 1976).

Variations in crustal magnetization on a more local scale also have been inferred from magnetic anomalies. One example is manifest in a commonly observed central linear high that lies at the center of the Brunhes magnetic anomaly (Klitgord, 1976; Carbotte and Macdonald, 1992). The central anomaly of the Endeavour segment of the Juan de Fuca Ridge possesses such a peak, locally exceeding $200 \mathrm{nT}$ in local relief and $5 \mathrm{~km}$ in width (Fig. 2; Tivey and Johnson, 1987). This central high is believed to be associated with the neovolcanic zone that contains on average the least altered and most strongly (but not most stably) magnetized rocks on the seafloor.

Local low anomalies and areas of inferred low magnetization are also found within the Brunhes anomaly. In most of these cases, the anomalies are of a small scale and have been observed primarily in deep-tow magnetometer surveys. Examples occur in the rift valley of 


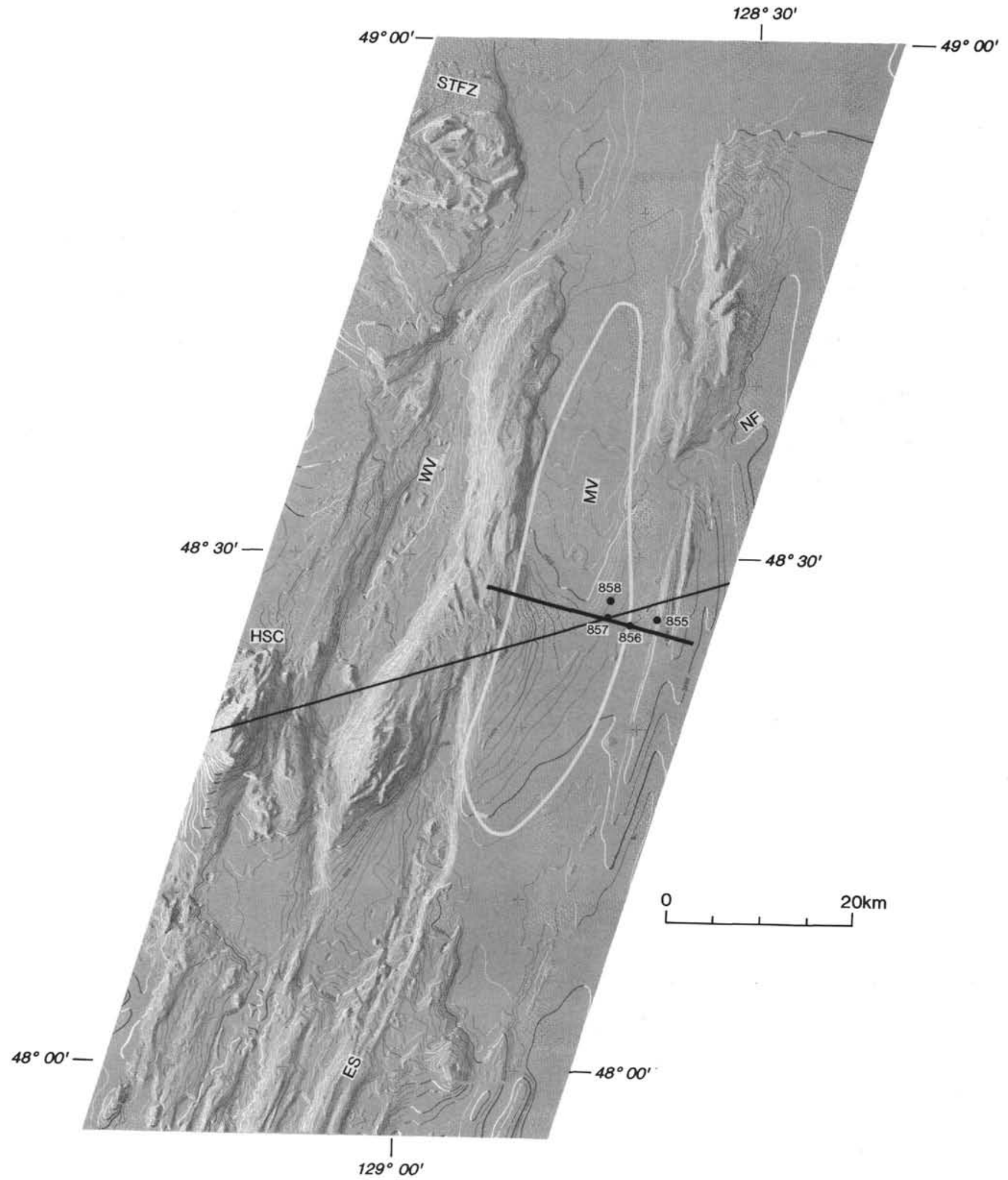

Figure 1. Bathymetry of the Middle Valley sedimented rift, with the Leg 139 drilling sites shown. The bold black line indicates the location of the profile presented in Figure 3 and the lighter line shows the location of the ship's track along which the magnetic data used in the models of Figure 5 were collected. The white line outlines the area underlain by hydrothermally altered igneous crust as inferred from the magnetic anomaly data (Fig. 2) and the model studies described in the text. The place names used in the text are abbreviated as follows: Sovanco Transform Fault Zone (STFZ), Middle Valley (MV), Endeavour Segment (ES), Nootka Fault (NF), Heck Seamount Chain (HSC) and West Valley (WV). 


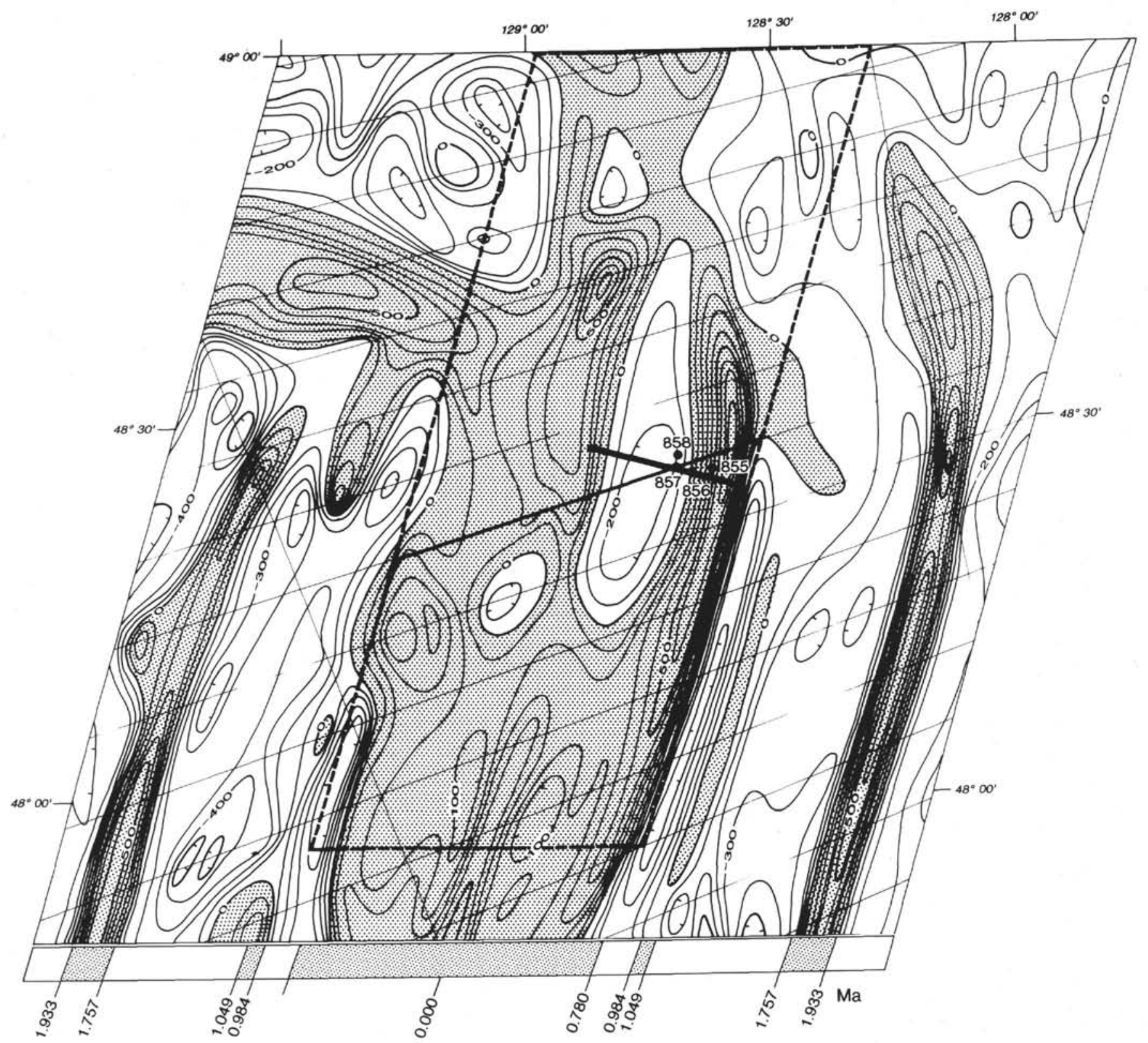

Figure 2. Sea-surface magnetic anomalies over the northern Juan de Fuca Ridge, with the area shown in Figure 1 outlined by a dashed line. The location of the Figure 2. Sea-surface magnetic anomalies over the northern Juan de Fuca Ragetic modelling described in the text and shown in Figures 4 and 5 is highlighted. The magnetometer line se been chosen to cover the full width of the Brunhes magnetic anomaly. The data have been projected onto a cross-strike line extending from length of the profile has been chosen to cover the full width of the Brunhes magnetic anomaly. The data have been projected on an Cande and Kent (1992), assuming the seismic profile (bold line) for the midne Valley magnetic low and the central magnetic high over the Endeavour ridge segment are clearly displayed.

the Mid-Atlantic Ridge (McGregor et al., 1977), in the Atlantis II deep of the Red Sea (Rona, 1978), and in the Endeavour segment of the Juan de Fuca Ridge (Tivey and Johnson, 1987). These anomalies are clearly associated with intense alteration of the upper igneous crust in areas of long-lived hydrothermal discharge.

\section{Sedimented Spreading Centers}

Similar levels of alteration occurring on a much larger scale are believed to be responsible for anomalously low-amplitude magnetic anomalies over crust that has been produced where sediments bury centers of spreading. Larson et al. (1972) discussed the lack of mag- netic anomalies in the sedimented basins of the Gulf of California and attributed this magnetic character to the slow cooling of the intrusive igneous rocks beneath the basins. The relationships between slow cooling and large grain size and between large grain size and low magnetization are well established (Verhoogen, 1959; Cox and Doell, 1962; Marshall and Cox, 1971). Atwater and Mudie (1973) report reduced magnetizations for sediment-covered parts of the Gorda Ridge. Other examples have been observed in which anomalously magnetized oceanic crust is inferred to have been produced over a long period of time. In the Andaman Sea off the Malay Peninsula, the magnetic anomaly pattern is of low amplitude over a broad area where sedimentation has been rapid over newly formed oceanic crust 
(Curray et al., 1978). Other examples of young oceanic crust not accompanied by typical linear magnetic anomalies include that lying beneath the Paul Revere Ridge and Winona Basin off northern Vancouver Island (Davis and Riddihough, 1982) and a broad zone adjacent to the Queen Charlotte Islands continental margin (Currie et al., 1979; Riddihough et al., 1980).

In all cases, the association of suppressed magnetic anomalies with early sediment burial of oceanic crust is unambiguous. Levi and Riddihough (1986) have discussed this association and reviewed several possible explanations, including the elevation of crustal temperatures into the range of magnetic blocking temperatures, slow cooling leading to large grain size and low remanent intensity, and hydrothermal alteration. Measurements made on samples collected from beneath the sediments of Middle Valley of the northern Juan de Fuca Ridge during Leg 139 provide definitive information concerning the cause of the low magnetization of igneous rock in these settings (Fukuma et al., this volume), and suggest that the last extensive alteration is the most important (see "Rock Magnetic Properties" section, this chapter).

\section{MIDDLE VALLEY}

The tectonic and magnetic structure of the northern end of the Juan de Fuca Ridge as revealed by bathymetry, magnetic, and seismic data is shown in Figures 1-3. The tectonic and volcanic history of the area is complex and includes the influence of the Heck and Heckle seamount chains, the instability of the plate geometry at the triple junction of the Juan de Fuca Ridge, the Sovanco transform fault, and the Nootka fault, and the recent initiation of spreading in West Valley (Davis and Villinger, 1992; Davis and Currie, 1993). These considerations are not important to the focus of this paper, however, and are not discussed here.

The direction and rate of spreading of the Juan de Fuca Ridge are best defined by the structurally simple Northern Symmetrical ridge segment that lies south of the Cobb offset, which is located at $47^{\circ} 40^{\prime} \mathrm{N}$, just south of the area shown in Figure 1 (Davis and Currie, 1993). This segment strikes in a direction of $021^{\circ}$ and spreads at a full rate of $54 \mathrm{~mm} / \mathrm{yr}$ (using the recently published $0.78 \mathrm{Ma}$ age for the Brunhes-Matuyama boundary of Spell and McDougall, 1992). Until recently, Middle Valley has been a part of the Endeavour segment, which is immediately north of the Cobb offset. The history of this segment is best defined on the eastern ridge flank, where off-axis magnetic anomalies extend uninterrupted from the Cobb offset to the latitude of the Sovanco transform zone, where the Juan de Fuca Ridge and Middle Valley now terminate (Figs. 1 and 2). The anomaly pattern is disrupted on the western flank by the magnetic signature of the Heck and Heckle seamount chains and by the deformation in the broad Sovanco transform fault zone. The central volcanic ridge of the Endeavour segment now plunges steeply along its axis to the north, currently extending over only a small portion of its former length. The axial magnetic high that lies above the Endeavour segment central volcanic ridge also dies to the north, disappearing completely near $48^{\circ} 15^{\prime} \mathrm{N}$.

Middle Valley lies directly along strike with the central part of the Endeavour ridge segment, and roughly central to the region estimated to be of Brunhes magnetic age (according to the eastern BrunhesMatuyama boundary and the seafloor spreading rate; Figs. 1 and 2). Over the valley, from roughly $48^{\circ} 15^{\prime} \mathrm{N}$ to the northern end at $48^{\circ} 45^{\prime} \mathrm{N}$, the central part of the Brunhes positive magnetic anomaly, which would include the axial magnetic high that characterizes the ridge axis further south, is replaced by an extensive negative magnetic anomaly that exceeds $-250 \mathrm{nT}$ with respect to the Definitive Geomagnetic Reference Field (DGRF) 1980 (Langel, 1992). This anomalous magnetic character has been the subject of discussion since the magnetic anomaly map of the region was first published by Raff and Mason (1961). Dehlinger et al. (1970) noted that the northern limit of Juan de Fuca Ridge was ill-defined both topographically and magnetically.
In another study of the region, Barr and Chase (1974) presented a number of models to explain the magnetic low. They concluded that underlying seafloor was probably reversely magnetized and hence older than 0.78 Ma. Davis and Lister (1977) argued that this conclusion was not reasonable, as it resulted in a spreading rate that was too slow compared with the rest of the ridge system, and they invoked basement relief and low magnetization due to elevated temperatures (see fig. 13, Davis and Villinger, 1992) and alteration to explain the magnetic low.

Magnetic studies carried out on igneous rocks sampled during Leg 139 (Shipboard Scientific Party, 1992a, 1992b; Fukuma et al., this volume) confirm the latter supposition, and the magnetic modelling described below demonstrates that the observed magnetic low over the valley can be fully attributed to the lack of crustal magnetization beneath the valley. The drilling sites in the valley were located primarily to address questions about the nature of hydrothermal circulation in the rift valley and about the processes controlling hydrothermal mineral deposition. The sites were fortuitously located with respect to the magnetic structure as well. Site 855 was drilled into igneous crust that appears to be producing a normal central magnetic anomaly. Sites 857 and 858 were drilled where the central anomaly is disrupted and replaced by the large negative anomaly (Figs. 1-3).

\section{MAGNETIC MODELLING \\ Magnetic Data}

The magnetic data used for this analysis (Fig. 2) were collected in 1983 by the Pacific Geoscience Centre aboard Parizeau using a Barringer OM104 marine proton precession magnetometer with a nominal 9-km line spacing (Currie et al., 1983, 1992). Navigation was provided by an Austron Model 5000 LORAN C receiver operating in range-range mode, with positions adjusted to TRANSIT satellite determinations. The observed values of the magnetic field were corrected for diurnal variations using an appropriately located base station and the regional field as defined by the International Geomagnetic Reference Field (IGRF) 1980 (Langel, 1992). In subsequent processing, the DGRF 1980 (Langel, 1992) was used to define the regional field for this survey. The mean crossover error was $2.1 \mathrm{nT}$ with a standard deviation of $17.7 \mathrm{nT}$ for the 153 ship's track crossings in the survey, which indicates that the data are of high quality. At Middle Valley, the declination was $22^{\circ}$, nearly identical to the strike of the ridge and associated magnetic anomalies, and the inclination was $69^{\circ}$ at the time of the survey. The profile used in the magnetic modelling was produced by projecting the observed magnetic anomaly data along the ship track highlighted in Figure 2 onto a line normal to the strike of Juan de Fuca Ridge.

\section{Rock Magnetic Properties}

To model the anomaly field in this region accurately, reliable estimates of magnetization are required for both "normal" seafloor in the vicinity of the spreading center and the material that underlies the Middle Valley magnetic low (MVML). Magnetization of the oceanic crust has been determined both from direct measurement of grab and drill samples as well as by proxy techniques.

\section{Normal Crust}

Irving et al. (1970) measured 38 samples dredged from the MidAtlantic ridge near $45^{\circ} \mathrm{N}$ and found a mean intensity of natural remanent magnetization (NRM) of $9.2 \mathrm{~A} / \mathrm{m}$. The mean susceptibility was two orders of magnitude less, attesting to the dominance of remanent magnetization in creating sea-surface magnetic anomalies. In a broader context, Lowrie (1977) observed that the average magnetization for 301 basalt samples from 55 Deep Sea Drilling Program (DSDP) ridge flank sites was $4 \mathrm{~A} / \mathrm{m}$, whereas the average for 112 dredge hauls was $14 \mathrm{~A} / \mathrm{m}$. Average Koenigsberger ratios (the ratio of 

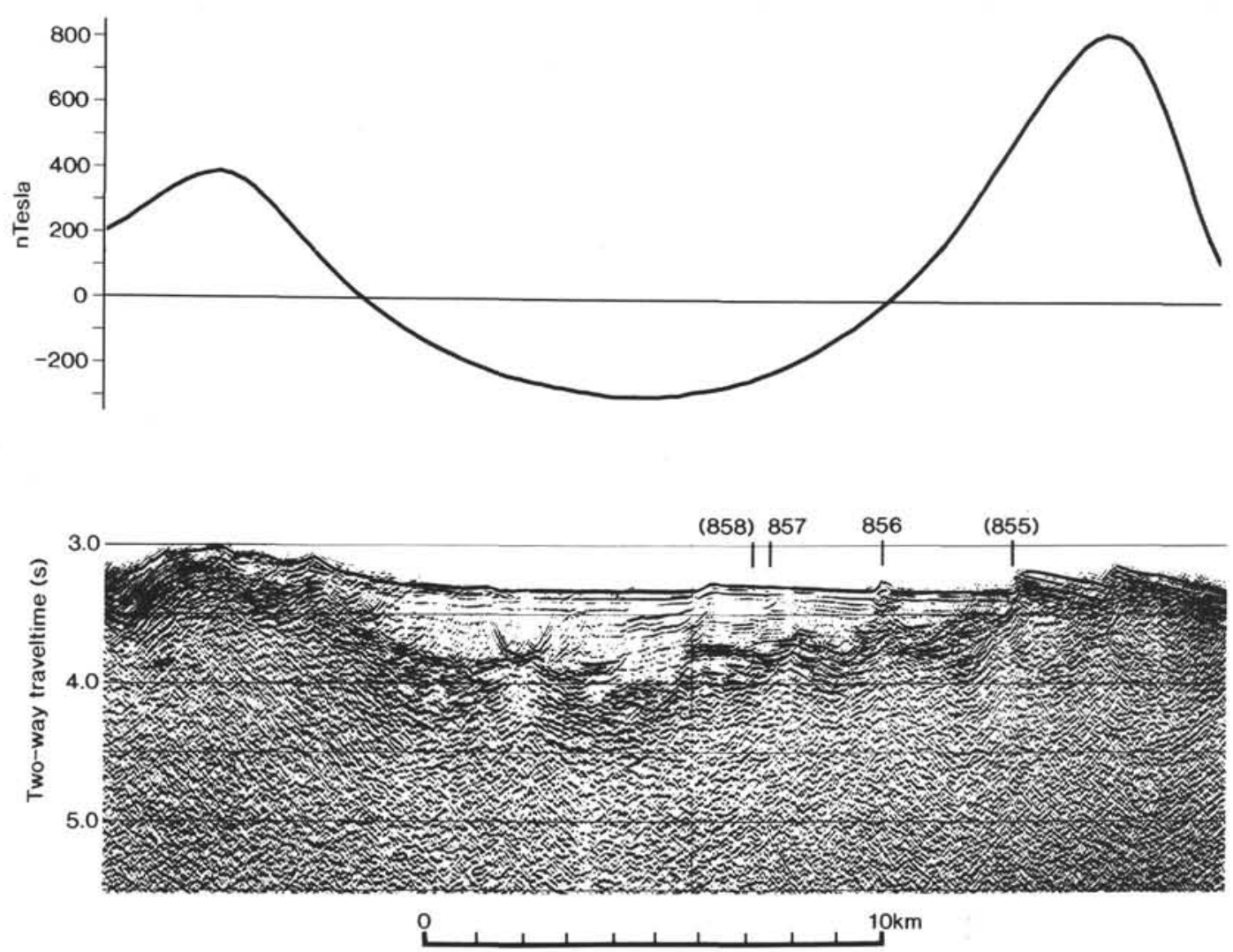

Figure 3. Cross-strike profile showing Leg 139 drill sites, projected sea-surface magnetic anomaly data, and multichannel seismic data. Tracklines are shown in Figures 1 and 2.

the NRM to the magnetization induced by the earth's field at the sample location) were 32 and 99 , respectively.

The most complete record of the magnetic structure of oceanic crust is provided by data from DSDP Hole 504B (Smith and Banerjee, 1986; Pariso and Johnson, 1991), located in 5.9 Ma crust in the eastern Pacific Ocean about $200 \mathrm{~km}$ south of the Costa Rica rift. The $1076 \mathrm{~m}$ of crust penetrated at that time could be divided into three major magnetic layers. The upper $500 \mathrm{~m}$ has an average NRM of 5.5 $\mathrm{A} / \mathrm{m}$; a $200-\mathrm{m}$ transition zone has an average NRM of $0.74 \mathrm{~A} / \mathrm{m}$; a lower 300-m zone extends to the bottom of the hole with an average NRM of $1.4 \mathrm{~A} / \mathrm{m}$. This site is too far from its spreading center to provide calibration for Brunhes age basalts, although it serves to demonstrate the dominance of the upper layer of extrusive rocks (as assumed in the models discussed below).

Proxy determinations of magnetization have been made by modelling deep-tow and sea-surface magnetic profiles. Assuming a constantthickness source layer of $0.5 \mathrm{~km}$ and two-dimensional bathymetry perpendicular to the profile, inversion techniques have yielded magnetizations of up to $10 \mathrm{~A} / \mathrm{m}$ for the Explorer Ridge, which lies to the north of the Sovanco transform fault (Botros and Johnson, 1988). In a geophysical study of Gorda Ridge, Atwater and Mudie (1973) calculated the strength of bulk magnetization $(0.5 \mathrm{~km}$ source layer) from deep-tow measurements over topographic features to be in the range of 15 to $30 \mathrm{~A} / \mathrm{m}$ for the youngest seafloor $(<200,000 \mathrm{yr})$ with moderate values ( 5 to $10 \mathrm{~A} / \mathrm{m}$ ) elsewhere. Their best fit to sea-surface magnetics over the central magnetic anomaly required a magnetization of $10 \mathrm{~A} / \mathrm{m}$. Anderson et al. (1975), also assuming a $0.5 \mathrm{~km}$ source layer, report a magnetization from sea-surface magnetics of about $18 \mathrm{~A} / \mathrm{m}$ for young ( $<3 \mathrm{Ma}$ ) crust on the Galapagos rift zone, and $6 \mathrm{~A} / \mathrm{m}$ on the Costa Rica rift. Modelling of deep-tow magnetics in the same areas yielded magnetizations of $30 \mathrm{~A} / \mathrm{m}$ and $10 \mathrm{~A} / \mathrm{m}$, respectively.

Observations most relevant to this study are those made directly on rocks obtained during Leg 139 . Site 855 was located on the eastern boundary of Middle Valley (Figs. 1 and 3). Typical extrusive oceanic basalts were recovered that had been buried subsequent to their eruption, but had never experienced high temperatures (Shipboard Scientific Party, 1992a; Simoneit, this volume). The rocks were fresh to slightly altered, from the foot wall and hanging wall of a rift-bounding normal fault, and buried beneath $100 \mathrm{~m}$ of sediment cover (Shipboard Scientific Party, 1992a). These samples had an average NRM of 9.7 $\mathrm{A} / \mathrm{m}$ with a Koenigsberger ratio of 19 (Table 2 in Fukuma et al., this volume), values comparable to other spreading ridges.

\section{Anomalous Crust}

For basalts in sediment-covered portions of the Gorda Ridge, Atwater and Mudie (1973) calculated magnetizations ranging from 2 to $5 \mathrm{~A} / \mathrm{m}$ ( $0.5 \mathrm{~km}$ source layer $)$. An inversion of sea-surface magnetics over the Gorda Ridge Sea Cliff hydrothermal field yielded negative magnetizations of $-2 \mathrm{~A} / \mathrm{m}$ for a $1.0 \mathrm{~km}$ source layer (Wooldridge et al., 1992). They also found that a magnetization of $0 \mathrm{~A} / \mathrm{m}$ would satisfy the sea-surface magnetics over some Mid-Atlantic hydrothermal areas. Samples dredged from the Mid-Atlantic Ridge hydrothermal areas had measured magnetizations as low as $0.35 \mathrm{~A} / \mathrm{m}$ (Wooldridge et al., 1990).

The measurements most relevant to this study are again those made directly on samples obtained from Middle Valley during Leg 139, in this case from Site 857, which lies beneath the magnetic low and sampled, according to the seismic reflection data, the most representative igneous rocks that lie beneath MVML of those drilled during Leg 139 (Figs. 1 and 3). These sills are intercalated with sediments and range from diabase to microgabbros in lithology (Shipboard Scientific Party, 1992b). Most samples were highly altered and yielded an average magnetization of $0.11 \mathrm{~A} / \mathrm{m}$, roughly two orders of magnitude less than the average for the Site 855 samples, and a Koenigsberger ratio of 1 (Table 3, Fukuma et al., this volume). The magnetization and susceptibility values are lower than any of those given above, and are believed 

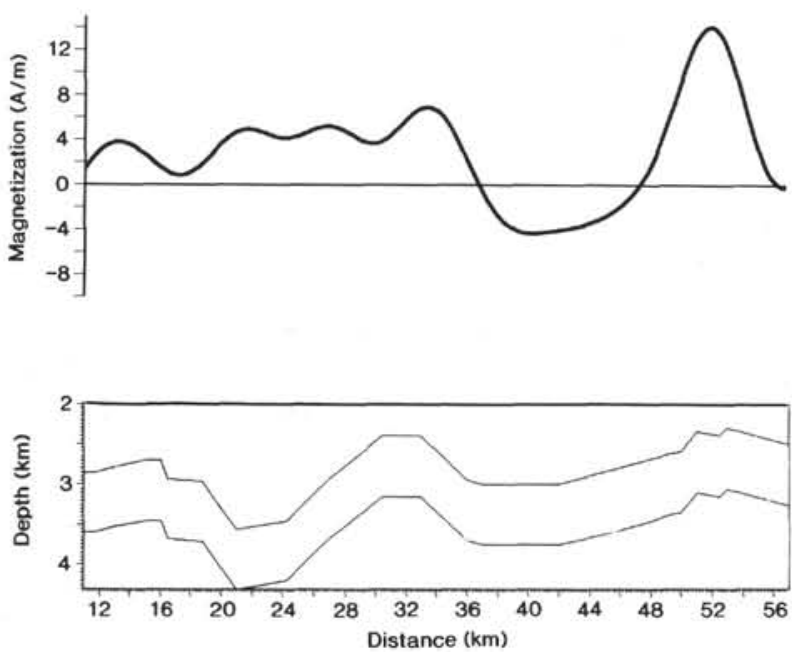

Figure 4. Magnetizations obtained from a 2-D inversion of the magnetic data in the presence of topography along the profile shown in Figure 1. to be caused primarily by extensive hydrothermal alteration. Fukuma et al. (this volume) report that the magnetic mineralogy at Site 857 is dominated by pure magnetite, that the magnetite is secondary in origin, and that the majority of the iron that normally resides in the primary Fe-Ti oxides that produce normal levels of magnetization has been removed by hydrothermal fluids and precipitated as nonmagnetic iron sulfide. The result is a unit with extremely low magnetization and susceptibility, the very properties required by the magnetic modelling discussed below. This mechanism implies the presence of pervasive fracturing to allow egress of hydrothermal fluids into all parts of the section that would normally possess strong magnetization. The fracturing need not extend into the deeper part of the section as low magnetization in the deeper section could be the result of elevated temperatures or slow cooling rates.

\section{Magnetic Models}

To determine magnetization distributions consistent with the observed sea-surface magnetic field, both inverse and forward modelling techniques have been applied to the data. We used the Fourier inversion method derived by Parker and Huestis (1974), assuming a
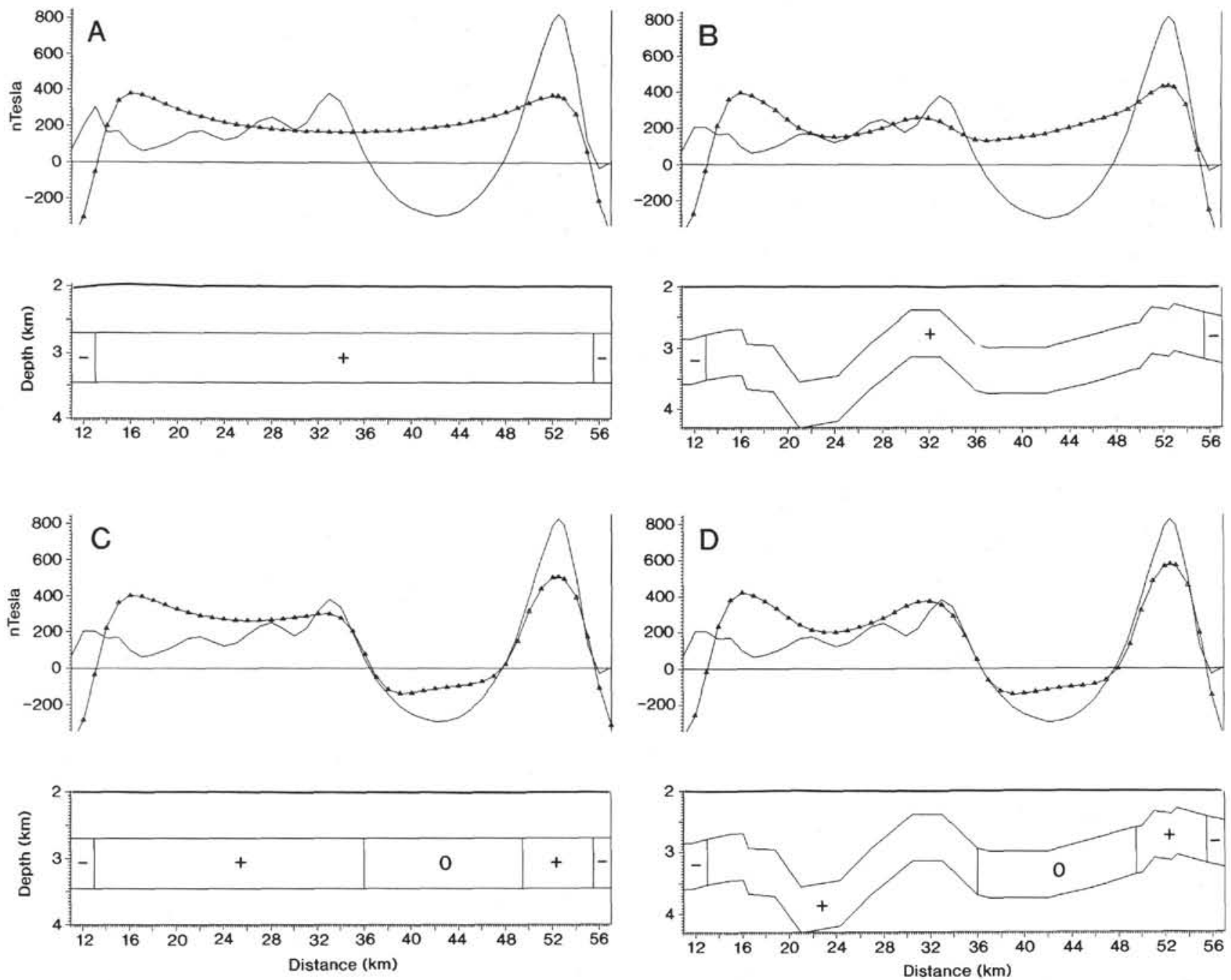

Figure 5. A comparison of the observed magnetic field (solid line) and the calculated field (triangles connected by solid line) for a variety of models along the profile shown in Figure 2. Unless otherwise noted, a magnetization of $9.7 \mathrm{~A} / \mathrm{m}$ has been used for normal $(+)$ and reversed $(-)$ seafloor. A. Expected Brunhes anomaly using the Juan de Fuca ridge spreading rate and simple source prism. B. Expected Brunhes anomaly using the Juan de Fuca ridge spreading rate and seismically determined basement topography. C. Model 5A with a zero magnetization prism underlying the MVML. D. Model 5B with a zero magnetization prism underlying the MVML. E. Profile across a simple 3-D model of the central anomaly, $50 \mathrm{~km}$ north of the Endeavour-Middle Valley normal to zero magnetization boundary. 
magnetic source layer of constant thickness with an upper surface constrained by seafloor bathymetry corrected for sediment thickness determined from seismic reflection data. This technique assumes that the magnetization can vary along the profile and is uniform with depth; the assumption of constant thickness precludes distinguishing zones of thin, highly magnetic crust from thicker, less magnetic crust.

Figure 4 shows the computed magnetization distribution assuming a 750-m source layer thickness. The range of magnetizations (typically 6 and up to $18 \mathrm{~A} / \mathrm{m}$ ) calculated across the central anomaly and Middle Valley is consistent with published values (see Grindlay et al., 1992) but the presence of strongly and negatively magnetized material in Middle Valley is not supported by the observations of rock magnetic properties as discussed in the preceding section. As the inversion technique does not lend itself to constrained magnetizations, forward modelling has been used to further assess the relationship between measured rock properties and the sea-surface magnetic anomaly.

Forward modelling was done using the "GRAMA" interactive two-dimensional gravity and magnetics modelling program (Geological Survey of Canada, 1990). The starting point was a simple hypothetical ridge segment model of the Brunhes and Matuyama using the geomagnetic polarity time scale of Cande and Kent (1992), a spreading rate of $54 \mathrm{~mm} /$ year and an average magnetization of 9.7 $\mathrm{A} / \mathrm{m}$ (Fukuma et al., this volume). An equivalent source thickness of $750 \mathrm{~m}$ was chosen to be within the depth range of an intermittent but common reflector (possibly the base of layer $2 \mathrm{~A}$ ) observed within layer 2 by Rohr et al. (1988) on multichannel seismic data across the crest and flank of the Endeavour Ridge segment immediately south of Middle Valley.

The resultant model profile (Fig. 5A) is clearly a poor approximation of the observed magnetic field and is only slightly improved by using the seismically determined depth to basement (fig. $9 \mathrm{~b}$ in Davis and Villinger, 1992) as the top of the source layer (Fig. 5B). Some local relief in the magnetic field is produced by the topography of the magnetic layer, but not nearly enough to match the observed field.

The next iteration involved introducing a zone of weakly magnetized material beneath the valley. A total magnetization of $0.22 \mathrm{~A} / \mathrm{m}$ was used initially, based on the measured magnetization $(0.11 \mathrm{~A} / \mathrm{m})$ and Koenigsberger ratio (1.0) at Site 857 (Fukuma et al., this volume). The contribution of this measured magnetization is effectively zero (less than $10 \mathrm{nT}$ ); it has been ignored in the discussions that follow and in the models shown in Figures 5C and 5D. A negative anomaly over the zone of low magnetization is predicted by these models that respectively ignore and include the topography of the magnetic layer.
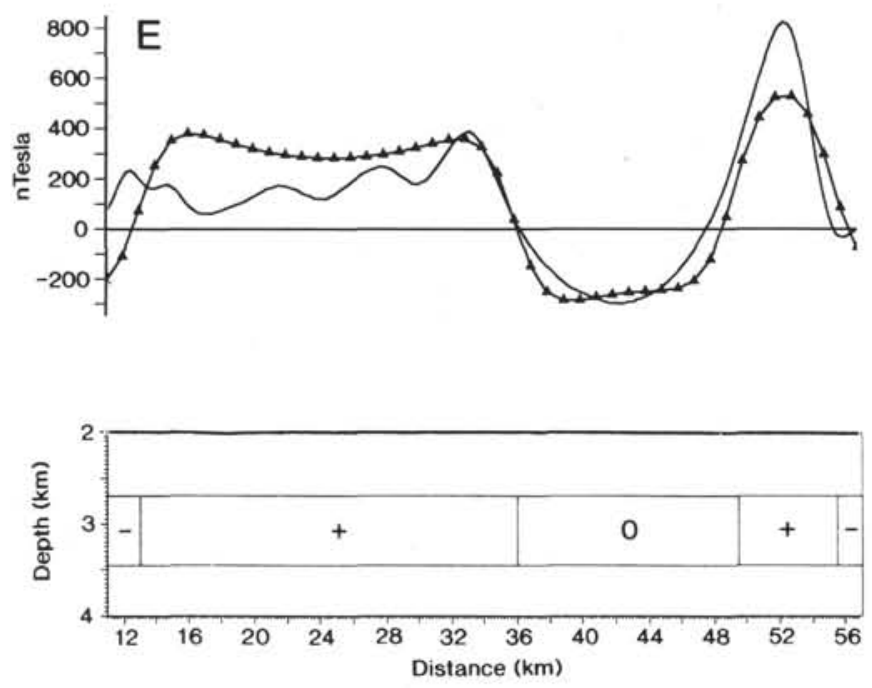

Figure 5 (continued).
It is clear that accurate representation of the topography of the magnetic layer is not important, because most of the topography occurs where the magnetization is extremely low. The negative magnetic anomaly is primarily a result of the edge effect of the slab of normally magnetized crust on either side of the valley.

Although the general character of the anomaly is reproduced, the amplitude of the modelled anomaly $(-150 \mathrm{nT})$ is not as great as observed (nearly $-300 \mathrm{nT}$ ). The amplitude can be matched, but this requires either an unrealistically thin $(<100 \mathrm{~m})$, highly magnetized source layer, or an improbable remanent magnetization direction $\left(\sim 100^{\circ}\right)$. Thus there remains a significant component $(\sim 1 / 2)$ of the magnetic anomaly that cannot be reasonably explained by the twodimensional models discussed above.

The final configuration considered is a simple 3-D model of the central anomaly that extends from the Cobb offset to the Sovanco transform fault. The three-dimensional forward technique of Talwani and Ewing (1960) was used with a source consisting of a flat slab 750 $\mathrm{m}$ thick having a cross section equal to Model $\mathrm{C}$ (Fig. 5) over Middle Valley and Model A (Fig. 5) over the Endeavour ridge segment. A magnetization of $14 \mathrm{~A} / \mathrm{m}$ was used for the crust outside Middle Valley, and a value of $0 \mathrm{~A} / \mathrm{m}$ was used for the crust within the valley. The profile shown in Fig. $5 \mathrm{E}$ is that computed $50 \mathrm{~km}$ to the north of the transition between the non- and positively magnetized central prisms. The match in amplitudes of the modelled and observed anomalies over Middle Valley suggests that the residual anomaly that was not explained by the two-dimensional models is due to the edge effect from the Endeavour segment to the south.

Although the fit is good well away from the southern limit of low crustal magnetization, this simple 3-D model produces a large $(\sim-600$ nT) negative anomaly adjacent to the boundary between the nonmagnetized (Middle Valley) and positively magnetized (Endeavour segment) crustal slabs that is not observed in the sea-surface magnetic data. The amplitude of this localized anomaly can be reduced by introducing a transition zone between the areas of normal and highly altered crust, which is physically reasonable.

At the eastern and western boundaries of the MVML, the agreement between the observed and modelled anomaly gradients (of all models) suggests that the transition between normal and nonmagnetic crust is sharp along the sides of the valley. Observed gradients are better matched with models having a sharp transition than those with transitions as narrow as $1 \mathrm{~km}$. A relatively sharp transition is also implied by the rapid change from positive to negative magnetization predicted by the inversion (Fig. 4). Because of the similarity of the local magnetic field declination and the strike of the ridge, the position of the "zero" contour (shown in Fig. 1) approximates the position of the normal-to-altered-crust boundary at positions greater than about $10-20 \mathrm{~km}$ from the northern and southern ends of the anomaly.

\section{Implications for the History of Crustal Burial}

The sharpness of the boundaries on both sides of the valley is remarkable. The linearity and position of the boundaries (Figs. 1-3) suggest that the major normal faults that currently bound the rift valley to the east and west have exerted a strong control on the sedimentation and the regional hydrothermal environment. It is likely that the transition between the normally magnetized crust outside the valley and the weakly magnetized crust beneath the MVML reflects a change from dominantly extrusive to dominantly intrusive crust, and more importantly, a change in the hydrothermal regime that has controlled the degree of alteration of the upper crust. Crust beneath the MVML has suffered extensive high-temperature alteration, whereas the normally magnetized crust can never have been affected by high-temperature hydrothermal circulation on a regional scale, and has probably experienced only cool and oxidizing conditions. Ogishima and Kinoshita (1992) have demonstrated the efficacy of hydrothermal circulation in destroying magnetic remanence and have shown that the alteration of 
titanomagnetites can take place in a matter of days when samples are subjected to the temperature $\left(350^{\circ} \mathrm{C}\right)$ and $\mathrm{pH}(3.0)$ conditions of an active hydrothermal environment. The "fresh" basalts used in their experiments having a Curie temperature of $200^{\circ} \mathrm{C}$ were altered to a low magnetic intensity phase with a Curie temperature about $480^{\circ} \mathrm{C}$. The intrusive basaltic rocks forming the upper crust beneath the MVML are well below the latter temperature, but may never have been below the former. Thus the remanence the altered rocks possess is stable but weak.

The presence of normally magnetized crust immediately outside Middle Valley indicates that the current structural style cannot be a steady-state feature of the area. The ridges bounding the valley to the east and west and the basaltic crust in the vicinity of Site 855 , although covered by sediment, must be underlain by more normal extrusive crust that was cooled by open hydrothermal circulation, with dominantly cool temperatures and effectively unrestricted fluid exchange across the seafloor. At the time of the production of this crust, roughly 0.78 to $0.44 \mathrm{Ma}$, a vigorous supply of magma, possibly related to the source responsible for the Heck seamount chain (Davis and Villinger, 1992), may have kept pace with the demands for crustal extension and kept the level of volcanism at or above the local baselevel of turbidite sediment supply.

A previous episode of sediment-buried rifting may have occurred to produce the area of low magnetic relief centered at roughly $48^{\circ} 30^{\prime} \mathrm{N}$, $128^{\circ} 30^{\prime} \mathrm{W}$ (Fig. 2) where the Matuyama reversed chron and Jaramillo normal subchron are obscured or absent. Over older crust, however, an uninterrupted magnetic anomaly sequence is observed; there crustal creation appears not to have involved a sedimented rift valley for any significant interval of time.

\section{CONCLUSIONS}

A deep negative magnetic anomaly is present over the current Middle Valley sedimented rift. The anomaly, which locally reaches nearly $-300 \mathrm{nT}$ in amplitude, is roughly centered in the area of the northernmost Juan de Fuca Ridge expected to be of normal (Brunhes) polarity, and is directly along strike from the axis of the Endeavour segment of the Juan de Fuca Ridge. Although inversion of the magnetic anomaly data shows that the presence of negatively magnetized crust is consistent with the data, forward magnetic models demonstrate that the anomaly can also be fully explained by a zone of low magnetization beneath the valley. The negative anomaly is produced by the edge effect of the normally magnetized crustal layers that bound the valley to the east, west, and south. There is no need to invoke a fortuitously located reversely magnetized crustal block to explain the anomaly. The magnetization and susceptibility used in the modelling to best match the magnetic field anomaly observed at the sea surface are fully compatible with values measured on igneous rocks collected during Leg 139 from areas of normal (Site 855) and anomalously low magnetization (Site 857) (Shipboard Scientific Party, 1992a, 1992b; Fukuma et al., this volume). The low magnetization and susceptibility of the rocks that lie beneath the Middle Valley magnetic low have been found to be due to dissolution and reprecipitation of iron during pervasive hydrothermal alteration. The thickness of the source layer outside the valley is broadly constrained, as a large-amplitude negative anomaly over the valley is not produced if the layer thickness is too great. The width of the transition between areas of normal and low magnetization is remarkably narrow, less than one kilometer on the east and west sides of the anomaly. The location of the transitions roughly coincide with the primary normal faults that currently bound the valley. The presence of strongly magnetized crust within the Brunhes magnetic chron outside the valley, and a nearly complete sequence of normal-amplitude seafloor spreading anomalies to the east of the valley suggest that the deep rift valley now present has not been a steady-state feature at this location along the Juan de Fuca Ridge.

\section{ACKNOWLEDGMENTS}

We would like to thank the Captain, officers, and crew of Parizeau for their assistance in collecting the sea-surface magnetic data used in this study. Jacob Verhoef of the Atlantic Geoscience Centre provided the program used for the magnetic inversion. The manuscript benefited from critical reviews provided by L.K. Law, R.L. Lawson, and an anonymous reviewer. Geological Survey of Canada contribution number 20493.

\section{REFERENCES}

Anderson, R.N., Clague, D.A., Klitgord, K.D., Marshall, M., and Nishimori, R.K., 1975, Magnetic and petrographic variations along the Galapagos spreading center and their relation to the Galapagos melting anomaly. Geol. Soc. Am. Bull., 86:683-694.

Atwater, T.M., and Mudie, J.D., 1973. Detailed near-bottom geophysical study of the Gorda Rise. J. Geophys. Res., 78:8665-8586.

Barr, S.M., and Chase, R.L., 1974. Geology of the northern end of Juan de Fuca Ridge and sea floor spreading. Can. J. Earth Sci., 11:1384-1406.

Botros, M., and Johnson, H.P., 1988. Tectonic evolution of the Explorer-northern Juan de Fuca region from $8 \mathrm{Ma}$ to the present. J. Geophys. Res., 93:10421-10437.

Cande, S.C., and Kent, D.V., 1992. A new geomagnetic polarity time scale for the Late Cretaceous and Cenozoic. J. Geophys. Res., 97:13917-13951.

Carbotte, E., and MacDonald, K., 1992. East Pacific Rise $8^{\circ}-10^{\circ} 30^{\prime} \mathrm{N}$ : evolution of ridge segments and discontinuities from SeaMARC II and threedimensional magnetic studies. J. Geophys. Res., 97:6959-6982.

Cox, A., and Doell, R.R., 1962. Magnetic properties of the basalts in hole EM7, Mohole project. J. Geophys. Res., 67:3997-4004.

Curray, J.R., Moore, D.G., Lawver, L.A., Emmel, F.J., Raitt, R.W., Henry, M., and Kieckhefer, R., 1978. Tectonics of the Andaman Sea and Burma. AAPG Mem., 29:189-198.

Currie, R.G., Cooper, R.V., Riddihough, R.P., and Seemann, D.A., 1983. Multiparameter geophysical surveys off the west coast of Canada: 19731982. Pap.-Geol. Surv. Can., 83-1A:207-212.

Currie, R.G., Davis, E.E., and Sawyer, B.S., 1992. Seafloor mapping of the western Canadian Exclusive Economic Zone. In Lockwood, M., and McGregor, B.A. (Eds.), Proc. 1991 Exclusive Economic Zone Symp. on Mapping and Research: Working Together in the Pacific EEZ. Geol. Surv. Circ. (U.S.), 1092:49-61.

Currie, R.G., Seemann, D.S., and Tiffin, D.L., 1979. Magnetic anomaly map of the Pacific Ocean west and northwest of Vancouver Island, British Columbia. Open-File Rep.-Geol. Surv. Can., 622.

Davis, E.E., and Currie, R.G., 1993. Geophysical observations of the northern Juan de Fuca ridge system: lessons in seafloor spreading. Can. J. Earth Sci., 30:278-300.

Davis, E.E., and Lister, C.R.B., 1977. Tectonic structures on the Juan de Fuca Ridge. Geol. Soc. Am. Bull., 88:346-363.

Davis, E.E., and Riddihough, R.P., 1982. The Winona Basin: structure and tectonics. Can. J. Earth Sci., 19:767-788.

Davis, E.E., and Villinger, H., 1992. Tectonic and thermal structure of the Middle Valley sedimented rift, northern Juan de Fuca Ridge. In Davis, E.E., Mottl, M.J., Fisher, A.T., et al., Proc. ODP, Init. Repts., 139: College Station, TX (Ocean Drilling Program), 9-41.

Dehlinger, P., Couch R.W., McManus, D.A., and Gemperle, M., 1970. Northeast Pacific structure. In Maxwell, A.E. (Ed.), The Sea (Pt. 2): New York (Wiley-Interscience), 133-189.

Geological Survey of Canada, 1990. GRAMA - an interactive 2.5 dimensional gravity and magnetic modelling program version 1.3. Open-File Rep.-Geol. Surv. Can., 2290.

Grindlay, N.R., Fox, P.J., and Vogt, P.R., 1992. Morphology and tectonics of the Mid-Atlantic ridge $\left(25^{\circ}-27^{\circ} 30^{\prime} \mathrm{S}\right)$ from Sea Beam and magnetic data. J. Geophys. Res., 97:6983-7010.

Irving, E., 1970. The Mid-Atlantic Ridge at $45^{\circ} \mathrm{N}$. XIV. Oxidation and magnetic properties of basalt; review and discussion. Can. J. Earth Sci., 7:1528-1538.

\footnotetext{
- Abbreviations for names of organizations and publications in ODP reference lists follow the style given in Chemical Abstracts Service Source Index (published by American Chemical Society).
} 
Irving, E., Park, J.K., Haggerty, S.E., Aumento, F., and Lancaravek, B., 1970. Magnetism and opaque mineralogy of basalts from the Mid-Atlantic Ridge at $45^{\circ} \mathrm{N}$. Nature, 228:974-976.

Johnson, H.P., and Holmes, M.L., 1989. Evolution in plate tectonics: a study of the Juan de Fuca Ridge. In Winterer, E.L., Hussong, D.M., and Decker, R.E. (Eds.), The Eastern Pacific Ocean and Hawaii. Geol. Soc. Am., Geol. of North Am. Ser., N:73-91.

Kappel, E.S., and Ryan, W.B.F., 1986. Volcanic episodicity and a non-steady state rift valley along Northeast Pacific spreading centers: evidence from Sea MARC I. J. Geophys. Res., 91:13925-13940.

Klitgord, K.D., 1976. Sea-floor spreading: the central anomaly magnetization high. Earth Planet. Sci. Lett., 29:201-209.

Langel, R.A., 1992. International geomagnetic reference field: the sixth generation. J. Geomagn. Geoelectr., 44:679-707.

Larson, P.A., Mudie, J.D., and Larson, R.L., 1972. Magnetic anomalies and fracture zone trends in the Gulf of California. Geol. Soc. Am. Bull., $83: 3361-3368$.

Levi, S., and Riddihough, R., 1986. Why are marine magnetic anomalies suppressed over sedimented spreading centers? Geology, 14:651-654.

Lowrie, W., 1977. Intensity and direction of magnetization in oceanic basalts. J. Geol. Soc. London, 133:61-82.

Macdonald, K.C., Fox, P.J., Perram, L.J., Eisen, M.F., Haymon, R.M., Miller, S.P., Carbotte, S.M., Cormier, M.-H., and Shor, A.N., 1988. A new view of the mid-ocean ridge from the behaviour of ridge-axis discontinuities. Nature, 335:217-225.

Marshall, M., and Cox, A., 1971. Effect of oxidation on the natural remanent magnetization of titanomagnetite in suboceanic basalt. Nature, 230:28-31.

McGregor, B.A., Harrison, C.G.A., Lavelle, J.W., and Rona, P.A., 1977. Magnetic anomaly patterns on Mid-Atlantic Ridge crest at $26^{\circ}$ N. J. Geophys. Res., 82:231-238.

Ogishima, T., and Kinoshita, H., 1992. Alteration of ferromagnetic components of oceanic basalt under pressurized hydrothermal liquids in laboratory. J. Geomagn. Geoelectr., 44:309-315.

Pariso, J.E., and Johnson, H.P., 1991. Alteration processes at Deep Sea Drilling Project/Ocean Drilling Program Hole 504B at the Costa Rica Rift: implications for magnetization of oceanic crust. J. Geophys. Res., 96:1170311722.

Parker, R.L., and Heustis, S.P., 1974. The inversion of magnetic anomalies in the presence of topography. J. Geophys. Res., 79:1587-1593.

Raff, A.D., and Mason, R.G., 1961. Magnetic survey off the west coast of North America $40^{\circ} \mathrm{N}$ latitude to $50^{\circ} \mathrm{N}$ latitude. Geol. Soc. Am. Bull., 71:1267-1270.

Riddihough, R.P., Currie, R.G., and Hyndman, R.D., 1980. The Dellwood knolls and their role in triple junction tectonics off northern Vancouver Island. Can. J. Earth Sci., 17:577-593.
Rohr, K.M.M., Milkereit, B., and Yorath, C.J., 1988. Asymmetric deep crustal structure across the Juan de Fuca Ridge. Geology, 16:533-537.

Rona, P.A., 1978. Magnetic signatures of hydrothermal alteration and volcanogenic mineral deposits in oceanic crust. J. Volcanol. Geotherm. Res., 3:219-225.

Shipboard Scientific Party, 1992a. Site 855. In Davis, E.E., Mottl, M.J., Fisher, A.T., et al., Proc, ODP, Init. Repts., 139: College Station, TX (Ocean Drilling Program), 101-160.

, 1992b. Site 857. In Davis, E.E., Mottl, M.J., Fisher, A.T., et al., Proc. ODP, Init. Repts., 139: College Station, TX (Ocean Drilling Program), 283-429.

Smith, G.M., and Banerjee, S.K., 1986. The magnetic structure of the upper kilometer of the marine crust at Deep Sea Drilling Project Hole 504B, Eastern Pacific Ocean. J. Geophys. Res., 91:10337-10354.

Spell, T.L., and McDougall, I., 1992. Revisions to the age of the BrunhesMatuyama boundary and the Pleistocene geomagnetic timescale. Geophys. Res. Lett., 19:1181-1184.

Talwani, M., and Ewing, M., 1960. Rapid computation of gravitational attraction of three-dimensional bodies of arbitrary shape. Geophysics, 25:203225.

Tivey, M.A., and Johnson, H.P., 1987. The central anomaly magnetic high: implications for ocean crust construction and evolution. J. Geophys. Res., 92:12685-12694.

Verhoogen, J., 1959. The origin of thermoremanent magnetization. J. Geophys. Res., 64:2441-2449.

Vogt,P.R., and Byerly, G.R., 1976. Magnetic anomalies and basalt composition in the Juan de Fuca-Gorda ridge area. Earth Planet. Sci. Lett., 33:185-207.

Vogt, P.R., and De Boer, J., 1976. Morphology, magnetic anomalies and basalt magnetization at the ends of the Galapagos high-amplitude zone. Earth Planet. Sci. Lett., 33:145-163.

Vogt, P.R., and Johnson, G.L., 1973. Magnetic telechemistry of oceanic crust? Nature, 251:373-375.

Wooldridge, A.L., Haggerty, S.E., Rona, P.A., and Harrison, C.G.A., 1990. Magnetic properties and opaque mineralogy of rocks from selected seafloor hydrothermal sites at oceanic ridges. J. Geophys. Res., 95:12351-12374.

Wooldridge, A.L., Harrison, C.G.A., Tivey, M.A., Rona, P.A., and Schouten, H., 1992. Magnetic modeling near selected areas of hydrothermal activity on the Mid-Atlantic and Gorda ridges. J. Geophys. Res., 97:10911-10926.

Date of initial receipt: 25 February 1993

Date of acceptance: 30 July 1993

Ms 139SR-201 